\title{
Purification of the Acetyl CoACarboxylase-1 from Serum of Breast Cancer Women after Mastectomy
}

\section{Sabah Gazal Mohammad ${ }^{1}$, Susan Jamil Ali ${ }^{1}$, Perry Habib Saifullah ${ }^{3}$}

1- Department of Chemistry, College of Education for pure Science, University of Tikrit, Iraq (sabahgazal@yahoo.com)

2- Department of Chemistry, College of Science for Women, University of Baghdad, Iraq

\begin{tabular}{|c|c|}
\hline Article Information & Abstract \\
\hline $\begin{array}{l}\text { Received: 09/08/2020 } \\
\text { Accepted: 15/09/2020 }\end{array}$ & $\begin{array}{l}\text { Acetyle CoA Carboxylase-1was purified from serum of premenop- ausal } \\
\text { women with breast cancer (after Mastectomy or treatment ) by Gel Filtration } \\
\text { using Sephadex G-100 and by Ion Exchange using DEAE-Cellulose A-50, } \\
\text { also the molecular weight was estimated by the Electrophoresis on }\end{array}$ \\
\hline Keywords: & $\begin{array}{l}\text { Acrylamide in the absence of denaturing elements. The result showed that a } \\
\text { single band was obtained at } 210 \mathrm{KD} \text { by Gel Filtering while Ion Exchange }\end{array}$ \\
\hline Breast Cancer, Acetyl CoA & showed one band at $210 \mathrm{KD}$. The optimum temperature of purified Acetyle \\
\hline $\begin{array}{l}\text { Carboxylase-1, activity, } \\
\text { purification and }\end{array}$ & $\begin{array}{l}\text { CoA Carboxylase- } 1 \text { was } 40^{\circ} \mathrm{C} \text {, optimal } \mathrm{pH} \text { at } 7.5 \text { and the optimum substrate } \\
\text { concentration at } 1.8 \mathrm{mM} \text {. Michaelis-Menten constant }(\mathrm{km}) \text { was } 0.3 \mathrm{mM} \text { and } \\
\text { Vmax was } 23 \mathrm{mM} \cdot \mathrm{min}^{-1} \text {. }\end{array}$ \\
\hline
\end{tabular}

\section{Introduction:}

Breast cancer (BC) continues to abruptly disrupt the lives of millions of women. Just this year (2018), 2.1 million new cases of BC are expected to be diagnosed worldwide [1,2].Breast cancer classification and patient stratification is crucial in terms of determining treatment strategy in clinic.

Breast tumors are classified into two groups: in situ (20\% of all cases) and invasive breast tumors (80\% of all cases). Based on their location, in situ breast cancers are further classified into two groups: ductal carcinoma in situ (DCIS $80 \%$ of in situ breast cancers) and lobular carcinoma in situ (LCIS20\% of in situ breast cancers). About 20-50\% of DCIS tumors can eventually progress to an invasive carcinoma [3]. Younger age at menarche, parity, and older age at first full-term pregnancy are well established risk factors for breast cancer. These risk factors may influence breast cancer risk through long-term effects on sex hormone levels in premenopausal women, through long-lasting changes in breast tissue, or by other biological mechanisms [4].

Acetyl-CoA carboxylase (ACC) (EC 6.4.1.2) is the mediates the first step of fatty acid synthese by carboxylation of acetyl-CoA to form malonyl-CoA and functions as a rate-limiting enzyme in fatty acid synthese. Two isoforms of ACC with distinct subcellular distribution and 
physiological roles have been identified, of which the cytosolic isoform ACC1 is predominant in control of the fatty acid synthesis, while the mitochondrial isoform ACC2 mainly regulates the fatty acid oxidation through inhibition of carnitine palmitoyltransferase I by localized malonyl-CoA production [5,6] Increased ACC1 expression is associated with several cancers including breast, liver lung, and prostate [7]. Elevated ACC expression is observed in the early stage of breast cancer,ACC activity is regulated in cancer cells through phosphorylation by AMPK $[8,9]$.

Early studies of purified rat liver enzyme indicated subunit MR of $215-230 \mathrm{kd}$ which could be further converted by proteolysis into two nonidentical subunits of MR $118 \mathrm{kd}$ and $125 \mathrm{kd}$. In more recent reports, two major protein bands (MR=240 and $260 \mathrm{kd}$ ) were found after SDS-PAGE when enzyme was purified from rat liver using polyethylene glycol precipitation . but only one major band (MR=260 kd) when an avidin affinity column was used to purify the enzyme .Regardless of the method of purification, determination of the subunit molecular weights of the purified enzyme may not reflect those of the native enzyme because the process may either alter its structure or favor the purification of one form preferentially [10].

Aim of study: Purification of the Acetyl CoA Carboxylase-1 after chemotherapy and radiotherapy for breast cancer patients and Calculate values $\mathrm{km}, \mathrm{V}$ max of enzymatic reaction.

\section{Material and Methods}

Material: All Chemical and Reagents were purchased from Sigma Aldrich / Germany, Fluka/ Switzerland, BDH / England, Pharmacia fine Chemical /Sweeden.

\section{Methods:}

Blood Sampling: The serum was obtained by intravenous extraction of blood in an amount of $3 \mathrm{ml}$, then the samples were placed in sterile tubes and left for about half an hour at room temperature to coagulate. After that, the serum was separated by a centrifuge at ( $4500 \mathrm{~g})$ for 10 minutes and then kept at $\left(-20^{\circ} \mathrm{C}\right)$ until the required tests were performed on it.

Estimation of ACC-1 activity: ACC-1 Activity was estimated spectrometry according to Kroeger method Include: the assay mixture $(450 \mu \mathrm{l})$ contained $100 \mathrm{mM}$ buffer phosphate $(\mathrm{pH}$ 7.8), $5 \mathrm{mM} \mathrm{MgCl}$, $4 \mathrm{mM}$ DTT, $10 \mathrm{mM}$ NaHCO3, $4 \mathrm{mM}$ ATP, $0.4 \mathrm{mM}$ NADPH, $0.4 \mathrm{mM}$ acetyl$\mathrm{CoA}$. The reaction (at $37^{\circ} \mathrm{C}$ ) was started by the addition of serum , Absorbance is measured at $365 \mathrm{~nm}$, photometric measurements were performed using a $500 \mu$ l cuvette with a $1-\mathrm{cm}$ path length [11].

Estimation of Protein: protein was determined by Kite Biomagrap Tunis.

Reference range: Serum total protein is 6 to $8 \mathrm{~g} / \mathrm{dl}[12,13]$.

Purification of ACC-1: The proteins were precipitated using different concentrations of ammonium sulfate from $30-60 \%$, so the optimum degree of saturation was $40 \%$ by adding (1.4gm) of ammonium sulfate gradually to the serum with stirring for 15 minutes, then separating the precipitate from the filtrate by a centrifuge cool at a temperature of $0{ }^{\circ} \mathrm{C}$ with a speed of $10000 \mathrm{~g}$ for 30 minutes, then the precipitate was dissolved with a little buffer phosphate at (100 mM, pH 7.8) and the activity and total protein were measured as shown in 
table 1 and proceeded into a further purification by gel filtration Chromatography applying into a Sephadex G-100 Column $(2.5 \times 40 \mathrm{~cm})$ using phosphate buffer ( $\mathrm{pH} 7.8,100 \mathrm{mM})$ as elution buffer, The flow rate $(1 \mathrm{~mL} / \mathrm{min})$ from the column and $5 \mathrm{~mL}$ of each fraction were collected. Where $125 \mathrm{ml}$ of phosphate buffer was passed through the gel column to ensure the descent of the enzyme by adding gradually and slowly so as not to crack the surface of the gel. The resultant was extra purified by Ion Exchange Chromatography using DEAE-Cellulose Column $(2.5 \times 25 \mathrm{~cm})$ and a washing solution consisting of phosphate buffer Solution $(20 \mathrm{mM}$, pH7.8) which contains (10 $\mathrm{mM}$ of sodium citrate) and the dilution solution that consists of phosphate buffer $(0.13 \mathrm{M}, 75 \mathrm{ml} ; 0.75 \mathrm{M}, 75 \mathrm{ml}$; pH7.8) which contains $(10 \mathrm{mM})$ of Sodium Citrate[14-16]. The flow rate (1 $\mathrm{mL} / \mathrm{min})$ from the column and $5 \mathrm{~mL}$ of each fraction were collected, After each purification step, concentrate the perfusion solution with glucose for 4 minutes before measuring activity and total protein. Therefore, the volumes used by the gel filtration and ion exchange method became few and concentrated.

Electrophoresis: Used Garfine method for electrophoresis Polyacrylamide under non denatured condition [17]. The molecular weight of the purified enzyme ACC-1 was measured compared to standard proteins standard proteins solution: Prepare to dissolve standard proteins Bovine albumin, albumin Eggs, Chymotrypsinogen, Lysozyme, Glucose Oxidas, Alcohol dehydrogenase and Immunoglobulins In the sample solution at a concentration of 5 $\mathrm{mg} / \mathrm{ml}$.

Temperature Effect: The effect of temperature on the purified enzyme (ACC) from sera at different temperatures $(20,25,30,37,40,45,50 \circ \mathrm{C})$ and the temperature was adjusted by thermostat and the activity was measured used Kroeger method [11].

pH Effect: The studied effect of the acid function on the purified serum solution the reaction mixture solutions were prepared in different acid function $(4.5,5,5.5,6,6.5,7,7.5,8,8.5,9)$ and the $\mathrm{pH}$ of the prepared solutions was adjusted by Hydrochloric acid (1M) and sodium hydroxide $(1 \mathrm{M})$ and the activity was measured used Kroeger method at optimum temperature.

Substrate Concentration Effect: The studied effect of the substrate (Acetyl Co-A) on the purified serum solution prepared concentrations different of substrate $(0.1,0.2,0.3,0.4,0.6$, $0.8,1.2,1.4,1.8,2 \mathrm{mM}$ ) and the activity was measured Used Kroeger method at optimum temperature and optimum $\mathrm{pH}$ [11]. The value(km) of the Substrate (Acetyl Co-A) of the ACC-1 purified enzyme from the blood Serum of women with breast cancer was calculated using the Lineweaver- Burk equation.

\section{Results and Discussion}

The result of ACC-1purification protocol could be illustrated in table1, Fig.1, Fig. 2and Fig. 3 
Table 1: purification of Enzyme ACC(ACC-1) from breast cancer serum for premenopausal after treatment or Mastectomy.

\begin{tabular}{|c|c|c|c|c|c|c|c|}
\hline Step & $\begin{array}{l}\text { Elute } \\
(\mathrm{ml})\end{array}$ & $\begin{array}{l}\text { Activity } \\
\text { (IU/ml) }\end{array}$ & $\begin{array}{c}\text { Total } \\
\text { activity } \\
\text { (IU) }\end{array}$ & $\begin{array}{c}\text { Total } \\
\text { protein } \\
(\mathrm{g} / \mathrm{dl})\end{array}$ & $\begin{array}{c}\text { Specific } \\
\text { Activity } \\
\text { (IU/g) }\end{array}$ & fold & $\begin{array}{c}\% \\
\text { Yield }\end{array}$ \\
\hline Grude Serum & 5 & 24.24 & 121.2 & 7.30 & 16.60 & 1 & 100 \\
\hline $\begin{array}{l}\text { Ammonium } \\
\text { Sulphates }\end{array}$ & 4 & 19.39 & 77.56 & 0.80 & 96.95 & 5.84 & 63.99 \\
\hline Dialysis & 3 & 17.81 & 53.43 & 0.33 & 161.90 & 9.75 & 44.08 \\
\hline Gel Filtration & 3 & 10 & 30 & 0.15 & 200 & 12.04 & 24.75 \\
\hline Ion exchange & 2 & 6.90 & 13.8 & 0.04 & 345 & 20.78 & 11.38 \\
\hline
\end{tabular}

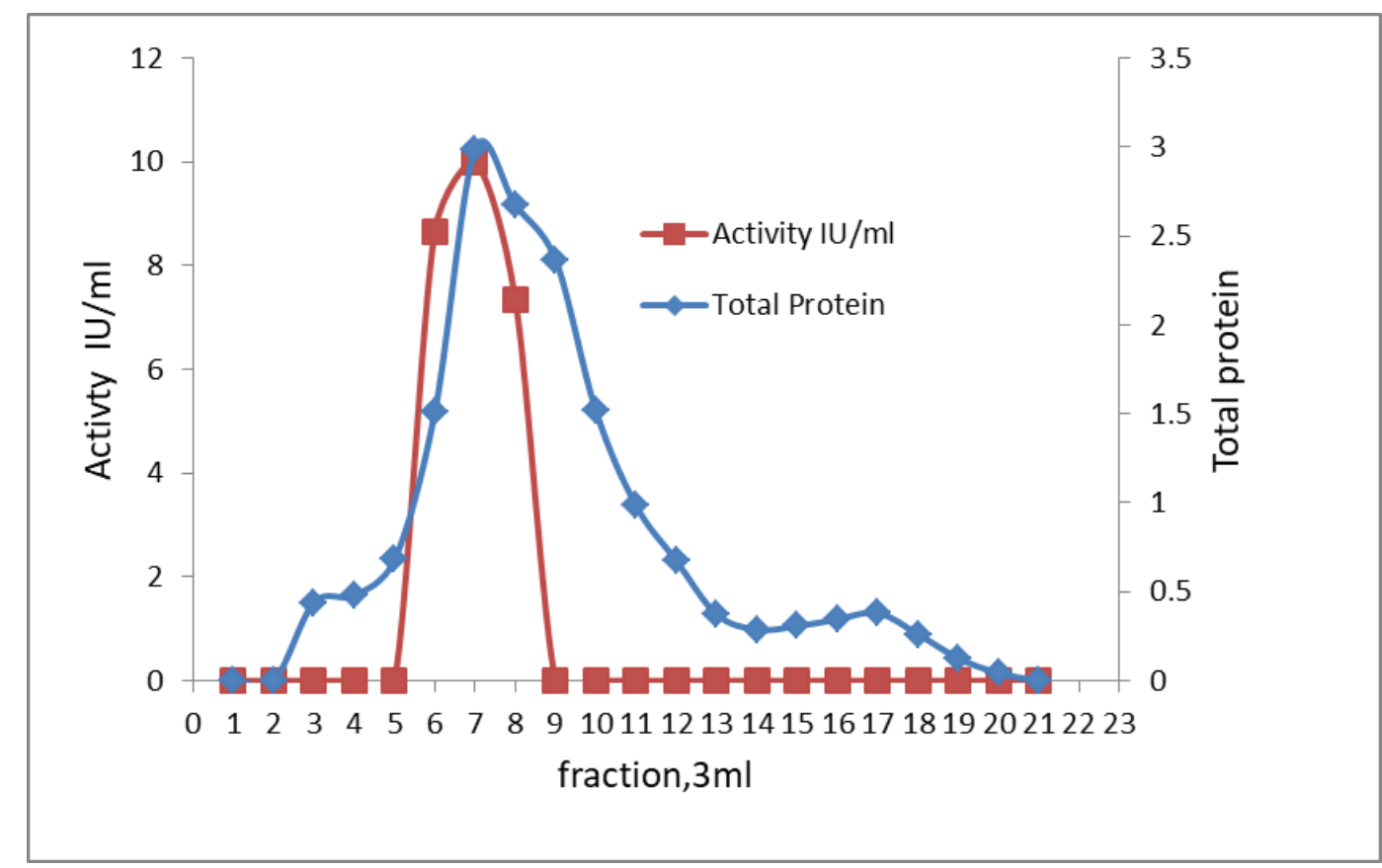

Figure 1: Gel filtration of ACC1 from breast cancer serums blood in premenopausal group after treatment or Mastectomy. 


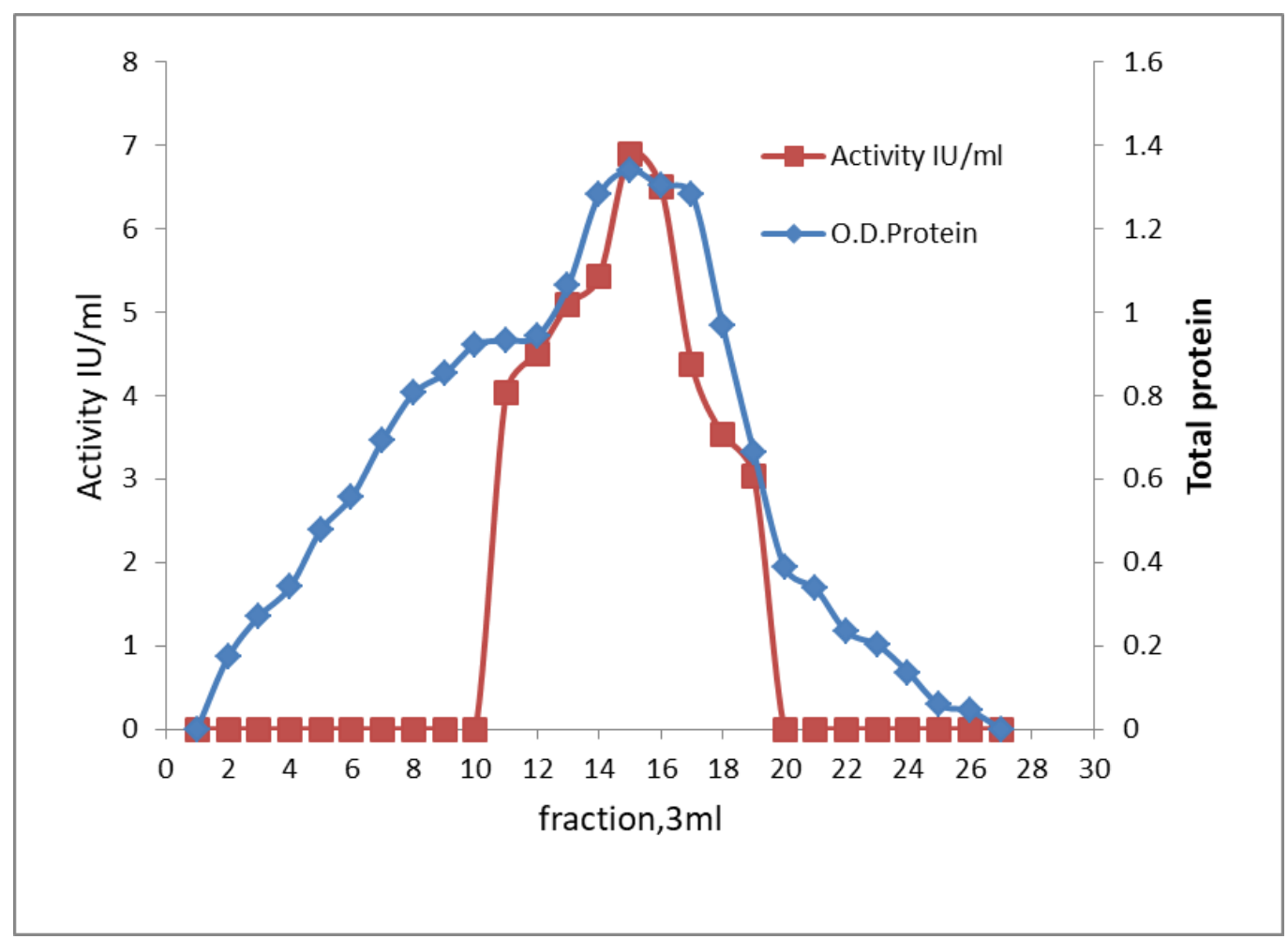

Figure 2: Ion exchange of ACC1 from serum with premenopausal breast cancer after treatment or Mastectomy

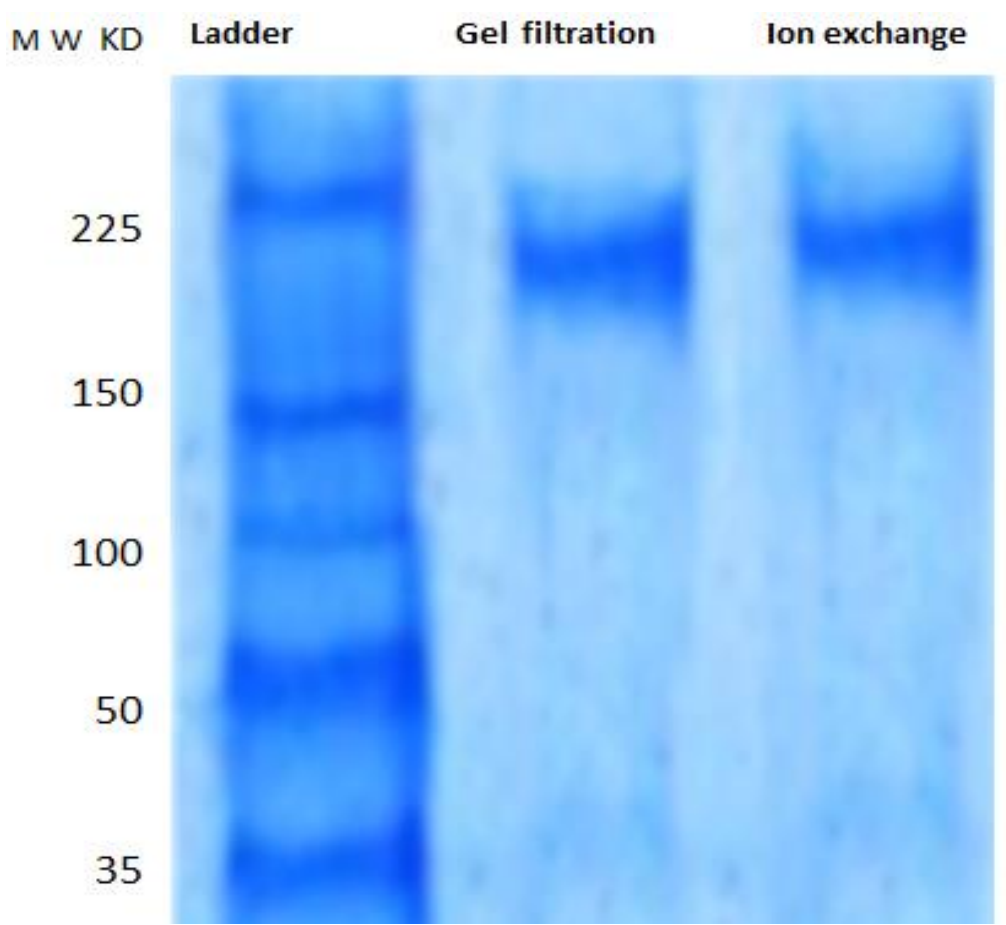

Figure 3: Electrophoresis of the purified ACC-1 enzyme from the serum of women with breast cancer premenopausal group for after treatment or Mastectomy.

Where the results showed a single peak in the gel filtering Chromatography and a single peak in the ion exchange Chromatography, as shown in Fig. 1 and 2. Electrophoresis on acryl amide, in the absence of denatured agents, the above results are proven, as it was observed that a single band appeared in the exudate part of the gel filtration as shown in Fig 
.3 molecular weight ( $210 \mathrm{kd})$ and ion exchange and molecular weights ( $210 \mathrm{kd})$ as shown in Fig .3.

These results are agree with the results of Beaty and his group, Where he is obtained one single peak of the purified ACC enzyme from chicken liver and obtained a band 210KD. [18]. It also agreed with Dehaye and his group where he obtained one single peak of the purified ACC enzyme from the seeds of the gel filtration method and he found the protein band at 210KD [19]. It also agreed with the findings of Roessler, where he obtained a band 200KD molecular weight using gel filter method [20], as well as with the chenge and his group, where the ACC enzyme was purified from humans and Rat, where a band was found at $210 \mathrm{KD}$ [21].

\section{Effect of Acidic function}

The Effected the acidic on speed of the enzymatic reaction through its effect on the ionic groups associated with the surface of the enzyme, where the ionic residues are taken in the active site of the enzymes and the creation of an enzymatic reaction that maintains the catalytic activity of the enzyme and Substrate, this $\mathrm{pH}$ agree with Manning and his group particularly the ACC-1 multiple enzyme that contains ionized residues in the centers reaction, the activity of charting the relationship between different degrees of the acidic function and reaction speed of the ACC- 1 enzyme. The reaction velocity is observed with an increase in $\mathrm{pH}$ to the limit of reaching the maximum speed at an acidic function of 7.5. [22,23], as shown in Fig. 4.

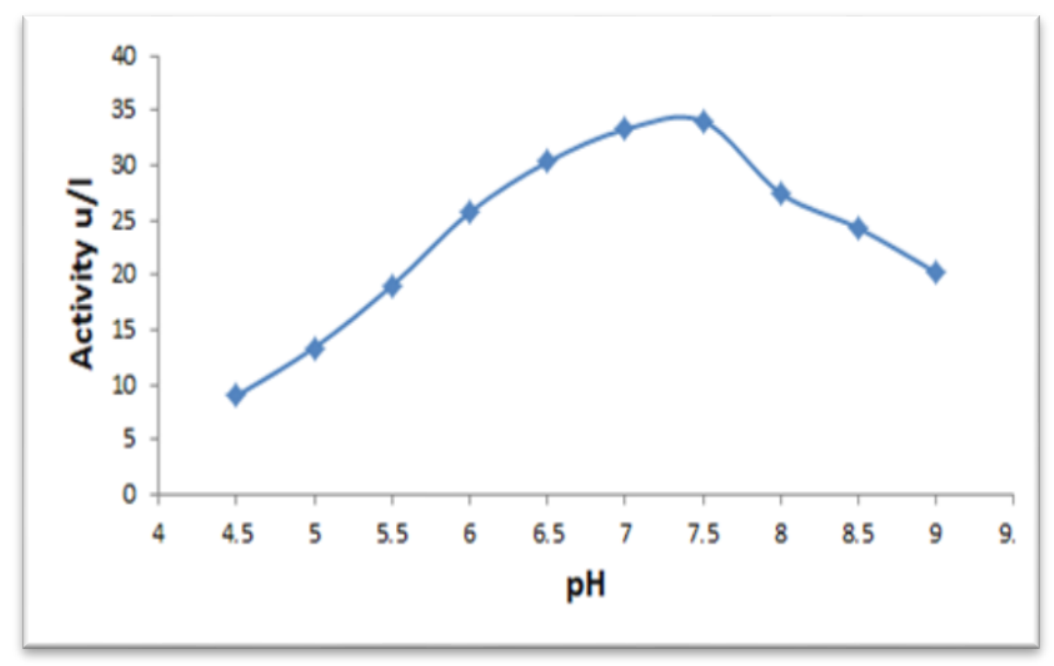

Figure 4: The effect of pH and Activity on ACC-1

\section{Temperature Effect}

Fig .5 shown the effect of temperature on the reaction speed of the ACC- 1 enzyme where a temperature rise is observed to reach the maximum reaction speed at a temperature of $40{ }^{\circ} \mathrm{C}$, then the reaction speed begins to decrease when the temperature increases above $40{ }^{\circ} \mathrm{C}$ and It is agree with Manning and his group Where the temperature affects in the case of ionization of the active groups present on the surface of the enzyme and the Substrate which leads to an increase in enzyme activity with increasing temperature because the enzymes are complex protein molecules, their catalytic activity affects the three-dimensional and even fourdimensional structure as the number of collisions between the enzyme and the substrate increases with increasing temperature At the same time, the enzyme cannot perform its 
catalytic role when the temperature rises to the extent that leads to a change in protein synthesis and the occurrence of denaturation processes, and then the enzyme loses its catalytic activity[22,23].

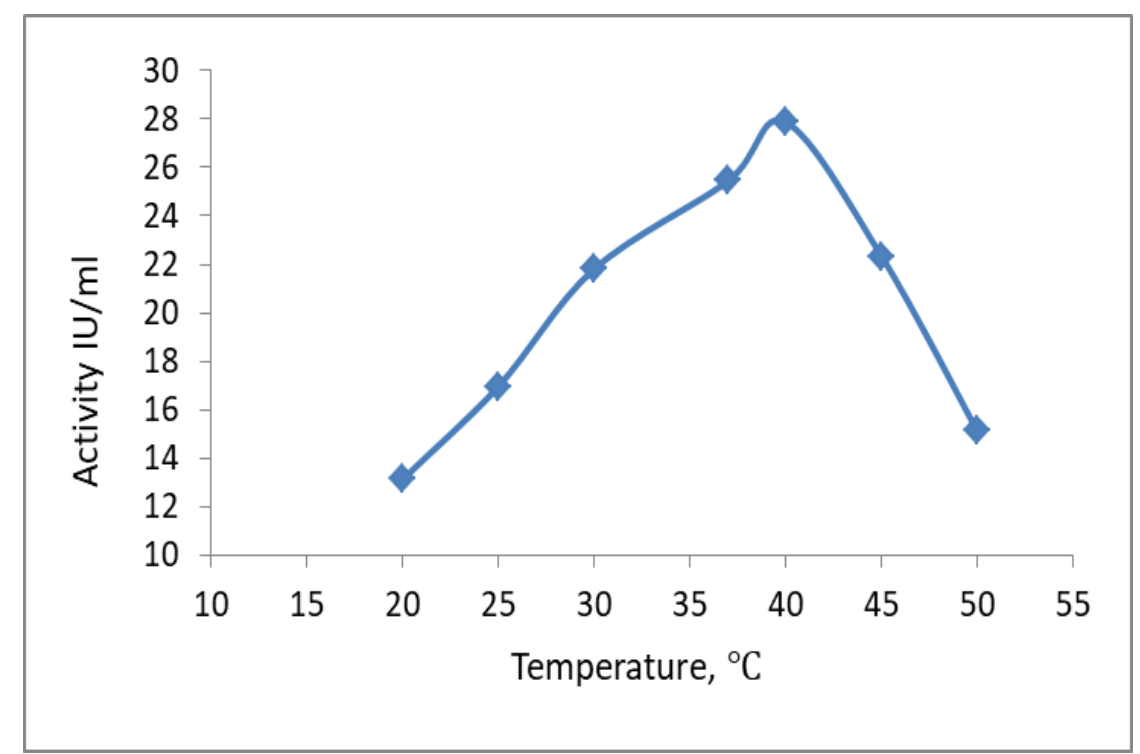

Figure 5: The effect of temperature on purified enzyme ACC-1

\section{Effect of Substrate Concentration (Acetyl CoA)}

The effect of the Substrate concentrations (Acetyl Co-A) on the speed of the enzymatic reaction was studied and the optimum concentration of this substance was determined, which gives the maximum reaction speed. Fig. 6 shows the effect of the concentration of (Acetyl CoA) on the speed of the ACC- 1 reaction. An increase in the reaction velocity is observed with an increase in the concentration of the Substrate until the maximum reaction velocity is reached at a concentration of (1.8mM.) Then the reaction speed is established as a result of saturation of sites activity of the enzyme ACC(ACC-1).

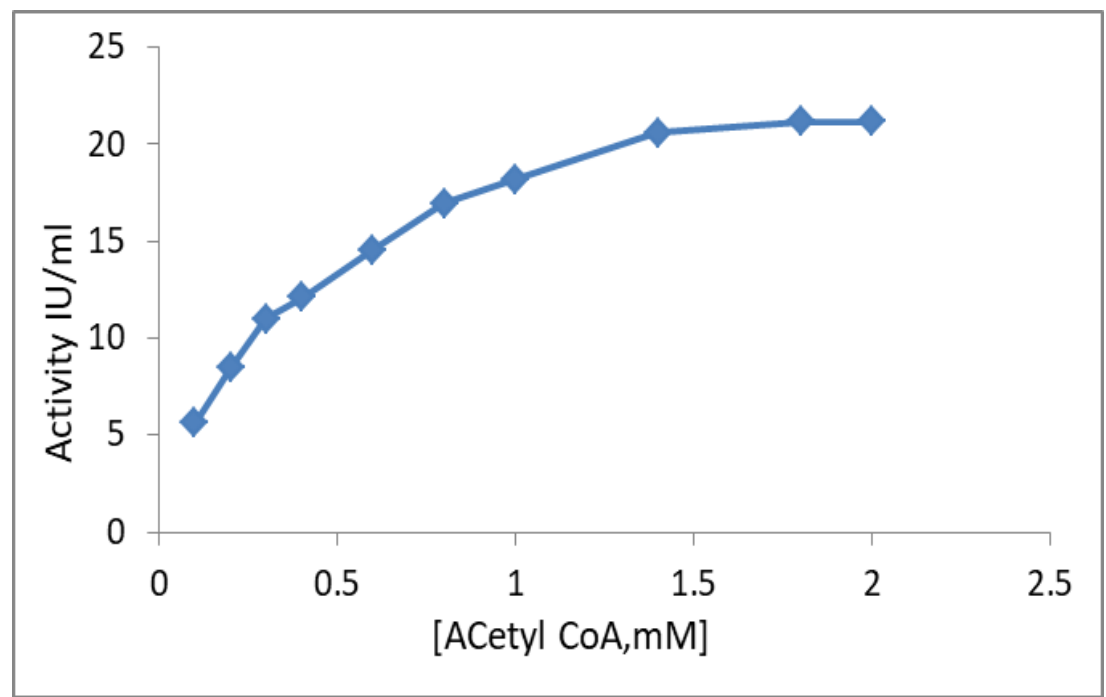

Figure 6: The effect of Substrate concentrations on the Activity of the purified ACC-1 
The Michaelis-Menten constant is one of the important physical constants in the kinetic studies of life compounds as it reflects the enzyme affinity of the substrate and it can be known that substrate concentration when the velocity of the enzymatic reaction is half of its maximum velocity (Vmax), Fig. 7.

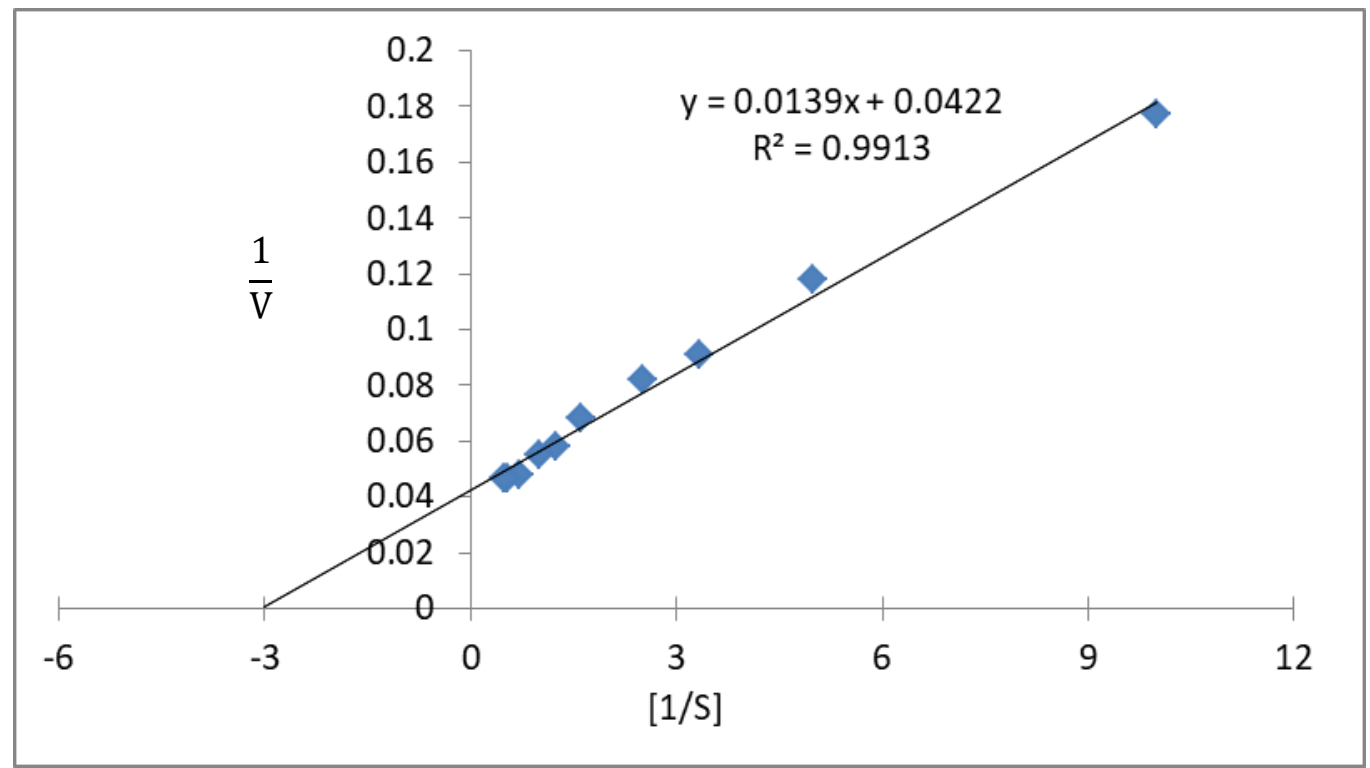

Figure 7: Lineweaver- Burk method for calculating the (Km)

Table 3: Values of Michaelis-Menten constant (km) and Vmax for ACC-1

\begin{tabular}{cccccc}
\hline Equation & Substrate & Con optimum & $\begin{array}{c}\mathrm{T} \\
\text { optimum }\end{array}$ & $\mathrm{Km}(\mathrm{mM})$ & Vmax \\
\hline $\begin{array}{c}\text { Lineweaver- } \\
\text { Burk }\end{array}$ & Acetyl CoA & $1.8 \mathrm{mM}$ & $40^{\circ} \mathrm{C}$ & 0.3 & $22 \mathrm{mM} \mathrm{min}^{-1}$ \\
\hline
\end{tabular}

Where shows table 3 the value of $\mathrm{km}$ and Vmax calculated according to the LineweaverBurk for Acetyle CoA the Substrate for the enzyme ACC(ACC-1) purified from serum with breast cancer at optimal conditions for the reaction the Km reflects a high affinity of the enzyme for substrate because a low concentration of substrate is needed to half saturate the enzyme that is reach a velocity of $1 / 2 \operatorname{Vmax}[24]$.

\section{Acknowledgements}

This research was conducted in the laboratories of the College of Sciences / University of Baghdad and in the Department of Water and Pollution / Ministry of Science and Technology.

\section{References}

1. Pal, T., Agnese, D., Daly, M., La Spada, A., Litton, J., Wick, M., ... \& Jarvik, G. P. (2020). Points to consider: is there evidence to support BRCA1/2 and other inherited breast cancer genetic testing for all breast cancer patients? A statement of the American College of Medical Genetics and Genomics (ACMG). Genetics in Medicine, 22(4), 681-685. 
2. Bray, F., Ferlay, J., Soerjomataram, I., Siegel, R. L., Torre, L. A., \& Jemal, A. (2018). Global cancer statistics 2018: GLOBOCAN estimates of incidence and mortality worldwide for 36 cancers in 185 countries. CA: a cancer journal for clinicians, 68(6), 394-424.

3. Kulkoyluoglu-Cotul, E., Arca, A., \& Madak-Erdogan, Z. (2019). Crosstalk between estrogen signaling and breast cancer metabolism. Trends in Endocrinology \& Metabolism, 30(1), 2538.

4. Coughlin, S.S. (2019). Epidemiology of Breast Cancer in Women. In: A. Ahmad (ed.), Breast Cancer Metastasis and Drug Resistance. Advances in Experimental Medicine and Biology, USA, 2 ed, Vol. 1152, p.13.

5. Li, E. Q., Zhao, W., Zhang, C., Qin, L. Z., Liu, S. J., Feng, Z. Q., ... \& Chen, C. P. (2019). Synthesis and anti-cancer activity of ND-646 and its derivatives as acetyl-CoA carboxylase 1 inhibitors. European Journal of Pharmaceutical Sciences, 137, 105010.

6. Hunkeler, M., Hagmann, A., Stuttfeld, E., Chami, M., Guri, Y., Stahlberg, H., \& Maier, T. (2018). Structural basis for regulation of human acetyl-CoA carboxylase. Nature, 558(7710), 470-474.

7. Davis, A. L., \& Kridel, S. J. (2016). Trimming the fat in non-small cell lung cancer: a new small molecule inhibitor of acetyl-CoA carboxylase to target fatty acid synthesis..

8. Mounier, C., Bouraoui, L., \& Rassart, E. (2014). Lipogenesis in cancer progression. International journal of oncology, 45(2), 485-492.

9. Bhattacharjee, K., Nath, M., \& Choudhury, Y. (2020). Fatty acid synthesis and cancer: Aberrant expression of the ACACA and ACACB genes increases the risk for cancer. Meta Gene, 100798.

10. Goodson, J., Pope, T. S., \& Allred, J. B. (1984). Molecular weights of subunits of acetyl CoA carboxylase in rat liver cytoplasm. Biochemical and Biophysical Research Communications, 122(2), 694-699.

11. Walker, S. W., Beckett, G. J., Rae, P., \& Ashby, P. (2013). Lecture Notes: Clinical Biochemistry. John Wiley \& Sons.

12. Chamberlain, R. S., Atkins, S., Saini, N., \& White, J. C. (2000). Ileal perforation caused by cytomegalovirus infection in a critically ill adult. Journal of clinical gastroenterology, $30(4), 432-435$.

13. Kroeger, J. K., Zarzycki, J., \& Fuchs, G. (2011). A spectrophotometric assay for measuring acetyl-coenzyme A carboxylase. Analytical biochemistry, 411(1), 100-105.

14. Hedhammar, M., Karlström, A. E., \& Hober, S. (2006). Chromatographic methods for protein purification. Stockholm: Royal Institute of Technology, 1-31..

15. Xie, Y., Han, X., \& Miao, Y. (2018). An effective recombinant protein expression and purification system in Saccharomyces cerevisiae. Current protocols in molecular biology, 123(1), e62..

16. Nakanishi, S., \& Numa, S. (1970). Purification of rat liver acetyl coenzyme A carboxylase and immunochemical studies on its synthesis and degradation. European Journal of Biochemistry, 16(1), 161-173.

17. Garfine, D.E. (1991).Purification Procedure: electrophoretic methods in :methods in Enzymology. Academic press, New York, (vol.182, p.425-441. 
18. Beaty, N. B., \& Lane, M. D. (1982). Acetyl coenzyme A carboxylase. Rapid purification of the chick liver enzyme and steady state kinetic analysis of the carboxylase-catalyzed reaction. Journal of Biological Chemistry, 257(2), 924-929.

19. Dehaye, L., Alban, C., Job, C., Douce, R., \& Job, D. (1994). Kinetics of the Two Forms of Acetyl-CoA Carboxylase from Pisum sativum: Correlation of the Substrate Specificity of the Enzymes and Sensitivity Towards Aryloxyphenoxypropionate Herbicides. European journal of biochemistry, 225(3), 1113-1123..

20. Roessler, P. G. (1990). Purification and characterization of acetyl-CoA carboxylase from the diatom Cyclotella cryptica. Plant Physiology, 92(1), 73-78.

21. Cheng, D., Chu, C. H., Chen, L., Feder, J. N., Mintier, G. A., Wu, Y., ... \& Tamura, J. K. (2007). Expression, purification, and characterization of human and rat acetyl coenzyme $A$ carboxylase (ACC) isozymes. Protein expression and purification, 51(1), 11-21.

22. Manning, R., Dils, R., \& Mayer, R. J. (1976). Purification and some properties of acetylcoenzyme A carboxylase from rabbit mammary gland. Biochemical Journal, 153(2), 463468.

23. Segel, I.R. (1968). Biochemcical calculations.John Wiley \& Sons,NewYork,p.208

24. Murray, K., Rodwell, V., Bender, D., Botham, K. M., Weil, P. A., \& Kennelly, P. J. (2009). Harper's illustrated biochemistry. 28 (p. 588). New York: McGraw-Hill. 
|RAQ Samarra Journal of Pure and Applied Science Academic Scientific Journals

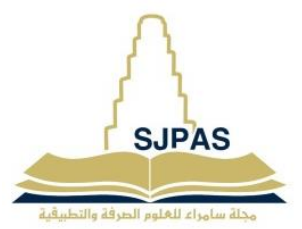

ISSN:2663-7405

تنقية الاستايل كواي كاربوكسليز-1 من مصل النساء المصابات بسرطان الثذي بعد استئصال الورم

صباح غزال حمح 1*، سوزان جميل علي1، بيري حبيب سيف الله2

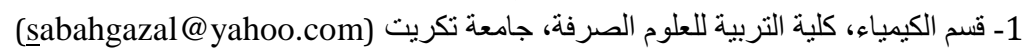

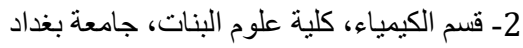

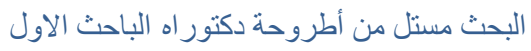

الخلاصةة:

تم تنقية انزيم الاستايل كواي كاربوكسليز من مصل النساء المصابات بسرطان

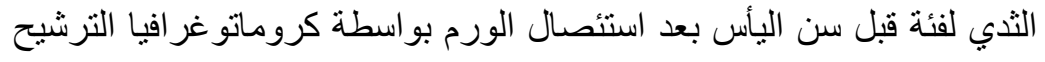

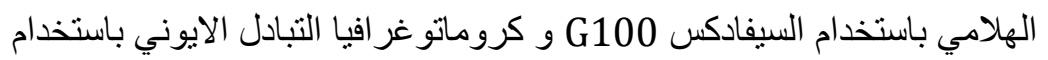

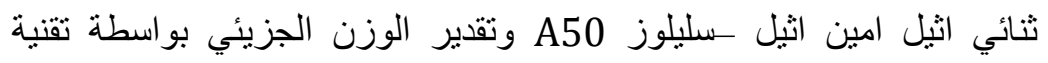

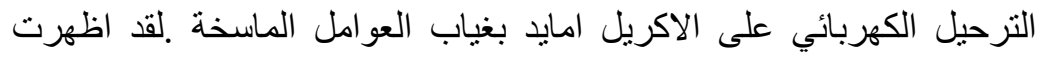

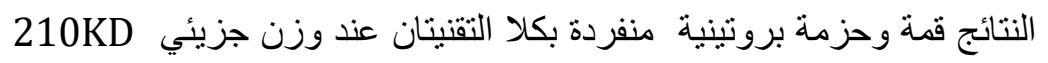

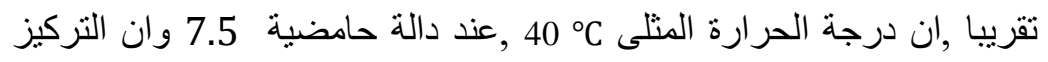

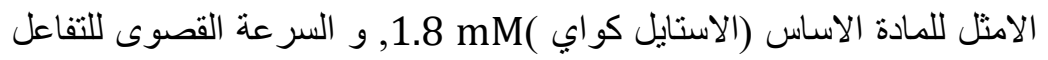
معلومات البحث:

\begin{tabular}{|c|}
\hline معلومات البحث: \\
\hline 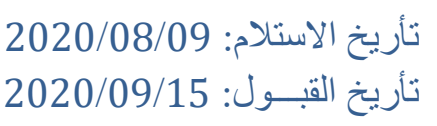 \\
\hline الكلمات المفتاحية: \\
\hline 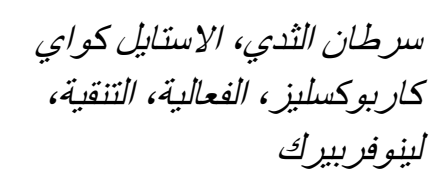 \\
\hline
\end{tabular}

$$
\text { الانزيمي 23mM/min وثابت ميكالس- منتن الاست }
$$

